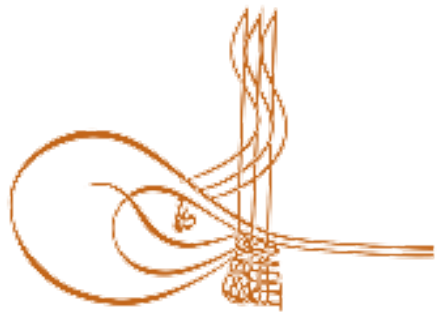

www.turkishstudies.net/education
Turkish Studies - Educational Sciences

eISSN: $2667-5609$

Research Article / Araștırma Makalesi

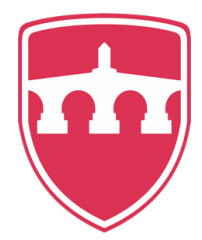

INTERNATIONAL

BALKAN

UNIVERSITY

Sponsored by IBU

\title{
Öğretmenlerin Minnettarlık, Psikolojik Sermaye ve İş Doyum Düzeyleri Arasındaki İlişkinin İncelenmesi
}

\author{
Examining The Relationship Between Teachers Levels of Gratitude, Psychological Capital and Job \\ Satisfaction
}

\author{
Serkan Cengiz ${ }^{*}$ - Önder Karadeniz ${ }^{* *}$
}

\begin{abstract}
The aim of this study was to examine the relationship between teachers job satisfaction, psychological capital and gratitude levels, and to determine whether their scores of gratitude levels showed differentiation by gender. Sample group of the study consists of 221 teachers working in primary school, secondary school and high school in central districts of Erzurum province. The research of group, $38 \%(\mathrm{n}=84)$ were male teachers and $62 \%(\mathrm{~N}=137)$ were female teachers. In order to reach the research data, personal data form was used to learn the gratitude scale, job satisfaction scale, psychological capital scale and information about teachers (gender, professional seniority). The arguments of the research are psychological capital and job satisfaction, and the dependent variable is gratitude. The pearson correlation method was applied to determine the relationship between teachers psychological capital levels and job satisfaction levels and gratitude levels. Multiple regression analysis was applied to determine the Predictor effect of teachers psychological capital levels and job satisfaction on gratitude levels. The t-test analysis method was also used for independent groups to determine whether teachers levels of gratitude differ significantly according to their gender. As a result of the research, it was found that there was a positively significant relationship between psychological capital and job satisfaction and gratitude. According to the results of multiple regression analysis, it was determined that the total scores of psychological capital and job satisfaction had a significant predictor effect on gratitude. In the t-test for independent samples to determine whether teachers levels of gratitude showed significant differentiation by gender, it was determined that female teachers experienced more feelings of gratitude than male teachers. The research data has been collected over time in 2019. The study was submitted to the Journal in 2020. For this reason, ethics committee permission was not obtained.
\end{abstract}

\footnotetext{
${ }^{*}$ Psikolojik Danışman, Yakutiye Rehberlik ve Araştırma Merkezi

Psychological Counseling, Yakutiye, Center for Guidance and Research

ORCID 0000-0001-9070-6338

srkn_cngz 25@hotmail.com

** Psikolojik Danışman, Palandöken Rehberlik ve Araştırma Merkezi

Psychological Counseling, Palandoken, Center for Guidance and Research

ORCID 0000-0001-8876-941X

onderkaradeniz@gmail.com

İlgili çalışmaya ait veriler 2019 yılında toplanmış olup, çalışma dergiye 2020 yılında gönderilmiştir. Dolayısıyla etik kurul izni alınmamıştır.
}

Cite as/ Atıf: Cengiz, S. \& Karadeniz, Ö. (2020). Öğretmenlerin minnettarlık, psikolojik sermaye ve iş doyum düzeyleri arasındaki ilişkinin incelenmesi, Turkish Studies - Education, 15(2), 717-730. https://dx.doi.org/10.29228/TurkishStudies.40571

Received/Geliş: 15 January/Ocak 2020

Accepted/Kabul: 24 April/Nisan 2020

Copyright $($ INTAC LTD, Turkey

Checked by plagiarism software

Published/Yayın: 30 April/Nisan 2020

CC BY-NC 4.0 
Structured Abstract: Introduction and purpose of study: Teachers, who are one of the cornerstones of the Turkish education system, can be exposed to many different problems today. If these problems are solved by the administrators of their existing schools and by the higher authorities they are affiliated to the problems will be solved and will contribute to the current education system.

Gratitude can be cited as one of the important concepts used in the field of Positive Psychology in recent years. Gratitude can be called pleasant experiences related to positive emotions (McCullough et al., 2001). Again, the concept of gratitude is called recognizing this benefit when a benefit is obtained from other people or entities, and responding with positive emotions (Emmons and Stern, 2013). A branch of the concept of capital, which is frequently used in the fields of Economics and investment, is the concept of psychological capital, which is based on the motivation of employees and their feeling of well being, which expresses the positive psychological state of the individual's development. One of the social environments in the life of the individual is the work environment. Work is defined as the activity that the person has done in order to achieve the necessary means to sustain his life in better conditions and to gain respect in the society in which he resides (Sahin, 2013).

When the relevant literature is examined, it is observed that there is a limited number of studies that may have an effect on teachers levels of gratitude. Especially in educational environments teachers show how important it is for them and increase their level of gratitude and gratitude is an important concept in positive psychology which are two variables that are not addressed with the concept of psychological capital and job satisfaction in terms of the concepts to be addressed in conjunction with this research will contribute to the literature, it is believed. Again, it is thought that the level of gratitude of teachers according to their gender and the lack of such a research finding makes this research important. It is also thought that the results of the research findings will contribute to similar research in the future. In conclusion, the aim of this study was to examine the effect of teachers psychological capital levels and job satisfaction levels on gratitude levels and to determine the differences in gratitude levels according to gender. For this purpose, answers to the following questions have been sought:

1 -) Does the psychological capital and job satisfaction levels of teachers predict the level of gratitude?

2 -) Do teachers levels of gratitude differ significantly according to their gender?

\section{Method}

The study explores the relationship between teachers ' levels of gratitude, psychological capital and job satisfaction. As a research method, the associative screening model has been used. The scanning model for determining whether two or more variables affect each other is called the relational scanning model (Büyüköztürk, 2015).

\section{Results}

Pearson correlation analysis to determine if there is a significant relationship between psychological capital and job satisfaction and gratitude found that there are positively significant relationships $(\mathrm{r}=.34, \mathrm{p}<.01$ $\mathrm{r}=.24, \mathrm{p}<.01)$. According to this, it can be said that if teachers psychological capital and job satisfaction levels increase, their level of gratitude will increase as well. Teachers psychological capital scores and job satisfaction scores indicate gratitude in a positive way $(\mathrm{R}=.37, \mathrm{R} 2=.13, \mathrm{~F}=16.88, \mathrm{p}<.05)$. The findings can be interpreted as that psychological capital and job satisfaction account for $13 \%$ of the variance in gratitude, and therefore, if teachers psychological capital and job satisfaction increase, their level of gratitude will also increase. Therefore, if teachers psychological capital and job satisfaction increase, their level of gratitude will also increase. İn order to determine whether or not gratitude levels differ significantly according to gender, independent samples t test showed significant gender differentiation in gratitude levels $(\mathrm{t} 221=-2.13, \mathrm{p}<.05)$. When arithmetic averages were examined to determine the source of the difference, it was observed that men had an arithmetic mean $(X=26.45)$ in their level of gratitude, whereas women had an arithmetic mean $(x=$ 28.13). According to this result, women's levels of gratitude are more than men's.

\section{Conculsion and recommendations}

The effect of teachers psychological capital and job satisfaction scores on their level of gratitude and whether there was a significant difference in their level of gratitude relative to gender was examined in this study. When the results of the research were examined, it was concluded that the increase in psychological 
capital and job satisfaction scores of teachers could also lead to an increase in gratitude levels. It was also determined that there was a significant difference in gratitude levels by gender and that women had a higher average score of gratitude levels than men.

As a result of this research, it may be suggested to determine the factors that can positively affect the psychological capital and job satisfaction of the teachers and to implement the improvement studies by the relevant stakeholders. Gratitude education programs can be determined according to the types and needs of the school and developed and implemented in the form of teacher, student and parent modules can be proposed. In addition, it may be suggested that the school administrators organize and implement the efforts to increase the level of gratitude in the form of writing gratitude for teachers and keeping a gratitude book. According to gender, women's level of gratitude was found to be higher than men's point averages. In future research for this finding, it may be suggested to investigate the sources of this situation by applying the interview technique, which is one of the qualitative research methods. The research covers the Central Districts of Erzurum province and the research data is limited by the responses of the participants to the scales. It may be suggested that similar research be applied by expanding the universe and sample group.

Keywords: Psychological Counseling, Gratitude, Psychological Capital, Job Satisfaciton, Teacher

Öz: Bu araştırmanın amacı öğretmenlerin minnettarlık, psikolojik sermaye ve iş doyumu düzeyleri arasındaki ilişkinin incelenmesi ve minnettarlık düzeyleri puanlarının cinsiyete göre anlamlı bir farklılaşma gösterip göstermediğini belirlemektir. Araştırmanın çalışma grubunu Erzurum ili merkez ilçelere bağlı ilkokul, ortaokul ve lisede görev yapmakta olan 221 öğretmen oluşturmaktadır. Araştırma grubunun \%38'ini $(\mathrm{n}=84)$ erkek öğretmen, \%62'sini $(\mathrm{n}=137)$ kadın öğretmen oluşturmaktadır. Araştırma verilerine ulaşabilmek için minnettarlık ölçeği, iş doyumu ölçeği, psikolojik sermaye ölçeği ile öğretmenler hakkında bilgilerin (cinsiyet, mesleki kıdem) öğrenilmesi amacıyla kişisel bilgi formu kullanılmıştır. Öğretmenlerin psikolojik sermaye düzeyleri ile iş doyumlarının minnettarlık düzeyleri ile olan ilişkisini belirlemek amacıyla pearson korelasyon analizi yapılmıştır. Öğretmenlerin psikolojik sermaye düzeyleri ile iş doyumlarının minnettarlık düzeylerine olan yordayıcı etki düzeyini belirlemek amacıyla çoklu regrasyon analizi uygulanmıştır. Yine öğretmenlerin minnettarlık düzeyleri cinsiyetlerine göre anlamlı bir farklılık gösterip göstermediğini belirlemek amacıyla bağımsız gruplar için t-testi analizi yönteminden faydalanılmıștır. Araştırma sonucunda psikolojik sermaye ve iş doyumu ile minnettarlık arasında pozitif yönde anlamlı bir ilişki olduğu bulunmuş̧ur. Yapılan çoklu regresyon analizi sonuçlarına göre, psikolojik sermaye ve iş doyumu toplam puanlarının minnettarlık üzerinde anlamlı yordayıcı etkiye sahip olduğu belirlenmiştir. Öğretmenlerin minnettarlık düzeylerinin cinsiyete göre anlamlı farklılaşma gösterip göstermediğini belirlemek amacıyla yapılan bağımsız örneklemler için t-testi uygulamasında, kadın öğretmenlerin erkek öğretmenlere göre daha fazla minnettarlık duygusu yaşadığı belirlenmiş̧tir. Araştırma verileri 2019 yılı içerisinde toplanmış olup, çalışma dergiye 2020 yılında gönderilmiştir. Bu sebepten dolayı etik kurulu izni alınmamıştır.

Anahtar Kelimeler: Psikolojik Danışmanlık, Minnettarlık, Psikolojik Sermaye, İş Doyumu, Öğretmen

\section{Giriş}

Türk eğitim sisteminin temel taşlarından birisi olan öğretmenler günümüzde çok farklı sorunlara maruz kalabilmektedir. Maruz kalınan bu sorunlara gerek mevcut okullarındaki yöneticilerden gerekse bağlı oldukları üst makamlar tarafindan çözüm üretilmesi durumunda sorunlar çözüme kavuşacak ve mevcut eğitim sistemine katkısı olacaktır. Psikolojik yönden kendini iyi hisseden öğretmen, veli, öğrenci ve okul yönetimi ile olumlu ilişkiler kurabilecek, okul başarısı yükselecek ve kişilerarası iletişimde olumlu yönde ilerlemeler sağlanacaktır. Bu sürecin olabilmesi adına da öğretmenlerin psikolojik kavramlar boyutunda desteklenmesi gerektiği söylenebilir. Bu psikolojik kavram boyutlarından birisi de minnettarlık kavramıdır.

Minnettarlık, son yıllarda pozitif psikoloji alanında kullanılan önemli kavramlardan birisi olarak gösterilebilir. Minnettarlık, olumlu duygularla ilgili hoşa giden yaşantılar olarak adlandırabilir (McCullough vd., 2001). Yine minnettarlık kavramı, başka insanlardan veya varlıklardan bir fayda 
elde edildiğinde bu yararı fark etme ve olumlu duygularla karşılık verme olarak adlandırılmaktadır (Emmons ve Stern, 2013). Tanımdan da anlaşılacağ 1 üzere minnettarlık kavramı sadece bireyin kendisine değil kendisi dışındaki çevreyi, olayları, durumları da temsil edecek bir kavram niteliği taşıdığı söylenebilir. Minnettarlık kavramının karşılık bulabilmesi adına yapılan yardımın bedelsiz olması, davranışın içtenliği ve yardım alan birey tarafından yapılan iyiliğin değerli bulunması şartlarının bulunduğu ifade edilmektedir (Araz ve Erdugan, 2017). Minnettarlık yaşantılarını elde etmenin ve bunları dış çevreye ifade etmenin insanların bedensel, ruhsal ve sosyal iyi oluşlarına olumlu katkılar sunmaktadır (Oğuz Duran ve Tan, 2013).

Alan yazında minnettarlık ile birlikte ele alınan araştırmalar incelendiğinde, Demirbağ (2016) tarafından öğretmenlerin minnettarlık düzeylerini artırma, üniversite öğrencilerinde minnettarlık yazma çalışmalarının etkisi (Işık-Terzi ve Ergüner-Tekinalp, 2017), çocuklarda minnettarlığın bazı değişkenlere göre ölçülmesi (Göcen, 2015), üniversite öğrencilerinde minnettarlık, bağışlanma ile kırılganlık arasındaki ilişkiye yönelik (İlbay ve Sarıçam, 2015) çalışmaların olduğu gözlemlenmiştir. Nitekim minnettarlı̆̆ etkileyen pek çok faktörden bahsedebiliriz. Bu faktörler arasında psikolojik sermaye ve iş doyumu kavramlarını da gösterebiliriz.

İktisadi ve yatırım alanlarında sıkça kullanılan sermaye kavramının bir koluna da çalışanların motivasyonu ve iyi hissetmeleri üzerine kurulu, bireyin gelişimine dair pozitif psikolojik durumunu ifade eden psikolojik sermaye kavramı oluşturmaktadır. Psikolojik sermaye kavramı başlarda genel olarak iktisadi, yatırım alanında kullanılmış ve ücret alanları ile olan ilişkisi incelenmiştir (Goldsmith vd.,1998). Psikolojik sermaye, bireyin kendisine kim olduğunu kanıtlayan, öz gelişimine katk1 sağlayan bir kavram olarak tanımlanabilir (Luthans ve Avalio, 2003). Bireyin, şimdiki zamanda ve gelecekte başarılı olabilmek adına pozitif beklenti içerisinde bulunma halidir (Özdemir ve Gören, 2016).

Psikolojik sermaye kavramı ile birlikte bireyin mevcut konumunda ve çalıştığ kurumda işlevselliğini artırmanın temel amaç olarak ele alındığ 1 belirtilmektedir (Peterson vd. 2011). Örgüt çalışanlarının bulundukları kurum içerisinde psikolojik yönlerine vurgu yapan psikolojik sermaye kavramı, çalışanların kendilerinden beklenen performansa ve farklılıklara vurgu yapan yapısı ile örgütsel yaşantı ve yapılara olumlu yansımalarının olduğu söylenebilir. Yapılan araştırmalarda, psikolojik sermayenin çalışanların iş performansına, çalıştıkları kurumlara olan bağl1lıklarına olumlu yönlerden katkısı olduğu belirtilmiştir (Aydın vd., 2013; Boamah ve Laschinger, 2011). Öğretmenlerin psikolojik sermayelerinin yüksek olması durumunda okullarına olan bağl1lıklarını artıracağı, okulların belirlenen amaçlarını kabullenme ve buna uygun hedefler oluşturma konusunda istekli hale geleceği belirtilmiştir (Yalçın, 2019). Öğretmenlerin psikolojik sermaye düzeylerine yönelik yapılan araştırmalar incelendiğinde, psikolojik sermaye kavramının bazı değişkenlere göre incelendiği (Kaya vd., 2014; Akman, 2016), pozitif psikolojik sermayelerine ilişkin algılarını belirlemeye yönelik yapılan çalışmalar (Tösten ve Özgan, 2017; Çakmak ve Arabac1, 2017), duygusal emek ile iş tatminleri arasındaki ilişkide psikolojik sermayenin aracılık rolü (Biçkes vd. 2014), psikolojik sermayeleri ile yeterlik inançları arasındaki ilişki (Kelekçi ve Yılmaz, 2015), psikolojik sermaye düzeyleri ile örgütsel vatandaşlık davranışları arasındaki ilişkinin incelenmesi (Bozgeyikli vd., 2017) çalışmalarına rastlanmıştır.

Bireyin yaşamında yer alan sosyal ortamlardan biriside iş ortamıdır. İş, insanın yaşamını daha iyi koşullarda sürdürebilmesi ve bulunduğu toplumda saygınlık kazanması adına gerekli olan araçlara ulaşabilmesi adına yapmış olduğu etkinlik olarak tanımlanmaktadır (Şahin, 2013). Bireylerin sahip oldukları işleri yerine getirme noktasında alacakları doyumun önemli olduğunu söyleyebiliriz. Çalışan bireylerin sadece sahip oldukları işlerde yüksek düzeyde başarı göstermesi ve işlerin aksamadan yürütülmesi değil aynı zamanda yaşam kalitelerinin, yapılan işte alınacak doyumun da artırılması gerekmektedir. İş doyumu, bireyin sahip olduğu işin gerektirdiği eylemleri yerine getirmesi sonucunda ortaya çıkan olumlu ruh hali olarak adlandırılmaktadır (Kara, 2010). 
Bireyin yaptı̆̆ 1 iş onun kişisel ihtiyaçlarını karşılamasının yanında onun değerlerini, mutluluğunu pozitif yönde etkiliyorsa iş doyumunun olduğunu söyleyebiliriz (Filiz, 2014).

Öğretmenlik mesleği de diğer meslek alanlarında olduğu gibi kendine özgü bazı zorluklar taşımaktadır. Eğitim politikalarında sıklıkla yapılan değişiklikler, veli ve öğrencilerin ilgilerindeki düşüklük, okul idaresi ile yaşanan sorunlar zaman zaman öğretmenlerin iş doyum düzeylerini olumsuz etkileyebilmektedir (Telef, 2011). Zamanının birçoğunu okulda öğrencileri ile birlikte geçirmek üzerine kurulu olan bu meslek alanında, öğretmeninin mesleki doyumunu sağlamak eğitim öğretimin kalitesini artırabilecek önemli faktörlerden birisi olarak değerlendirilebilir.

Alanyazında öğretmenlerin iş doyumları üzerine yapılan çalışmalara sıç̧a rastlamak mümkündür. Öğretmenlerin iş doyumlarına yönelik yapılan çalışmalarda mesleki tükenmişlik (Dilsiz, 2006; Ertürk ve Keçecioğlu, 2012), denetim odağı (Canbay, 2007), sinıf yönetim becerileri (Akın ve Koçak, 2007), diğer öğretmenlerle olan ilişkiler (Yakut ve Certel, 2016), yalnızlık düzeyleri (Çifçi ve Dikmenli, 2015), mutluluk (Terzi, 2017) gibi farklı değişkenlerle çalışıldığı görülmektedir.

İlgili literatür incelendiğinde öğretmenlerin minnettarlık düzeylerine etki edebilecek sınırlı sayıda araştırmanın bulunduğu görülmektedir. Özellikle eğitim ortamlarında öğretmenlerin minnettarlık düzeylerini artırmanın onlar adına ne kadar önemli olduğunu göstermesi, cinsiyete göre minnettarlık puanlarındaki anlamlı farklılı̆̆ 1 içeren çalışma sayısının kısıtlılığı ve pozitif psikolojinin önemli bir kavramı olan minnettarlık kavramının daha önce birlikte ele alınmayan iki değişken, "psikolojik sermaye ve "iş doyumu" kavramları ile birlikte ele alınması bakımından bu araștırmanın alanyazına katkı sunacağı düşünülmektedir. Sonuç olarak bu araştırmada öğretmenlerin psikolojik sermaye düzeyleri ile iş doyum düzeylerinin minnettarlık düzeylerine olan etkisinin incelenmesi ve cinsiyete göre minnettarlık düzeylerinde farklılaşma durumlarının belirlenmesi amaçlanmıştır. Bu amaç doğrultusunda aşağıdaki sorulara cevap aranmıştır:

1-) Öğretmenlerin psikolojik sermaye ve iş doyum düzeyleri minnettarlık düzeylerini anlamlı bir düzeyde yordamakta mıdır? midir?

2-) Öğretmenlerin minnettarlık düzeyleri cinsiyetlerine göre anlamlı farklılık göstermekte

\section{Yöntem}

Araştırmada öğretmenlerin minnettarlık, psikolojik sermaye ve iş doyum düzeyleri arasındaki ilişki araştırılmaktadır. Araştırma yöntemi olarak, ilişkise tarama modeli kullanılmıştır. İki ya da daha fazla değişkenin birbirini etkileyip etkilemediğini ortaya çıkarmaya yarayan tarama modeline ilişkisel tarama modeli denilmektedir (Büyüköztürk, 2015). Araştırmanın bağımlı değişkenini minnettarlık oluştururken, bağımsız değişkenlerini ise cinsiyet, psikolojik sermaye ve iş doyumu oluşturmaktadır.

\section{Çalışma Grubu}

Araştırmanın çalışma grubunu, Erzurum ili merkezinde görev yapan 221 öğretmen, oluşturmaktadır. Öğretmenlere ait demografik bilgiler Tablo 1'de gösterilmiştir. 
Tablo 1: Öğretmenlerin Demografik Özellikleri

\begin{tabular}{lccl}
\multicolumn{2}{l}{ Demografik Özellikler } & N & $\mathbf{\%}$ \\
\hline Cinsiyet & Kadın & 137 & 62 \\
& Erkek & 84 & 38 \\
\hline K1dem & $1-5$ y1l & 34 & 15,4 \\
\hline & $6-10$ y1l & 57 & 25,8 \\
\hline & $11-15$ y1l & 46 & 20,8 \\
\hline & $16-20$ y1l & 42 & 19 \\
\hline Toplam & 20 y1l üzeri & 42 & 19 \\
\hline & & 221 & 100 \\
\hline
\end{tabular}

Tablo 1' de öğretmenlerin öğretmenlerin cinsiyetlerine göre dağılımları incelendiğinde öğretmenlerin \%38'nin erkek ( $\mathrm{n}=84), \% 62$ 'sinin kadın $(\mathrm{n}=137)$ olduğu belirlenmiştir. Öğretmenlerin mesleki kıdemlerine göre dağılımları incelendiğinde, \%15,4'nün ( $\mathrm{n}=34), 1-5$ y1l, \%25,8'nin $(\mathrm{n}=57)$, 6-10 yıl, \%20,8'nin ( $\mathrm{n}=46), 11-15$ yıl, \%19'nun ( $\mathrm{n}=42), 16-20$ yıl, \%19'nun (n=42), 20 yıl üzeri olduğu görülmüştür.

\section{Veri Toplama Araçları}

Araştırmada verilerin toplanmasında katılımcıların sosyo-demografik özelliklerini belirlemek için kişisel bilgi formu, minnettarlık ölçeği, psikolojik sermaye ölçeği ve minnesota iş doyum ölçeği kullanılmıştır. Araştırmada kullanılan ölçek formlara ait bilgiler aşağıda bulunmaktadir.

\section{Kişisel Bilgi Formu}

Araştırmaya katılan öğretmenlerin cinsiyetlerini, mesleki kıdem düzeyleri hakkında bilgi alabilmek adına oluşturulan formdur.

\section{Minnettarlık Ölçeği}

Yetişkinlerin minnettarlık düzeylerini belirlemek amacıyla kullanılan minnettarlık ölçeği, McCulough, Emmons ve Tsang (2002) tarafindan geliştirilmiştir. Ölçeğin Türkçeye uyarlanması, geçerlik ve güvenirlik çalışmaları ise Yüksel ve Oğuz-Duran (2012) tarafından yapılmıştır. Orijinalinde 6 madde olan ölçek uyarlama çalışmalarından sonra 6. maddenin ölçek dışı kalması sebebiyle 5 madde ve yedili likert tipinden oluşmaktadır. Ölçekte bulunan 3. madde ters maddedir. Ölçeğin madde toplam korelasyon değerleri .83 arasında değişmektedir. Bu araştırma için güvenirlik katsayısı değeri .74 olarak hesaplanmıştır.

\section{Psikolojik Sermaye Ölçeği}

Psikolojik sermaye ölçeği Luthans vd. (2007) tarafindan geliştirilmiş, Türkçeye uyarlanması Akçay (2014) tarafında yapılmıştır. Ölçek özyeterlilik, iyimserlik, umut ve esneklik olmak üzere toplam dört alt boyuttan oluşmaktadır. Ölçekte üç tane ters madde bulunmaktadır. Ölçeğin bütününe ait güvenilirlik katsayısı değeri .97 olarak tespit edilmiştir. Bu araştırma için ölçeğe ait güvenirlik katsayısı değeri 90 olarak hesaplanmıştır.

\section{İş Doyumu Ölçeği}

Bireylerin mesleki doyum düzeylerini belirlemek amaciyla kullanılan minnesota doyum ölçeğinin kısa formu ilk kez, Dawis ve arkadaşları (1967) tarafından geliştirilmiştir. Ölçeğin Türkçeye uyarlanması, geçerlik ve güvenirlik çalışmaları ise Baycan (1985) tarafından yapılmıştır. 100 sorudan oluşan ölçeğin uyarlanma çalışması sonrası 20 maddeye düşürüldüğü gözlemlenmişstir. 
Beşli likert tipinde oluşturulan ölçeğin içsel ve dişsal tatmin boyutu olmak üzere toplam iki alt boyutu bulunmaktadır. Ölçekte ters madde bulunmamaktadır. Ölçeğin bütününe ait güvenirlik değeri .91 olarak tespit edilmiştir. Bu araştırmada da ölçeğe ait güvenirlik katsayısı değeri .91 olarak tespit edilmiştir.

\section{Verilerin Toplanması}

Araştırmaya katılan öğretmenler, farklı okul türlerinden rastgele olarak belirlenmiştir. Gerekli uygulama izinlerinin ardından, öğretmenlere araştırmanın amacından ve araştırma sürecinden bahsedilmiştir. Teneffüs araları beklenerek veri toplama araçları, araştırmacılar tarafından uygulanmıştır. Çalışmaya katılım gönüllülük ilkesine bağlı olup istekli öğretmenlerden veri toplanmıştır. Çalışmada toplam 250 ölçme aracı uygulanmış ve elde edilen tüm ölçek formları incelenmiştir. İnceleme sonucunda uç değer olarak tespit edilen 29 veri çalışma haricinde tutulmuş̧tur.

\section{Verilerin Analizi}

Verilerin analizinde öğretmenlerin, cinsiyete göre minnettarlık düzeyleri arasında anlamlı farklılık olup olmadığı ' 'bağımsız örneklemler için $t$ testi'" ile incelenmiştir. Yine öğretmenlerin, minnettarlık, psikolojik sermaye ve iş doyum düzeyleri arasındaki ilişkiler ise Pearson korelasyon analizi ile saptanmıştır. Bununla birlikte psikolojik sermaye ve iş doyumunun minnettarlık düzeyi üzerindeki yordayıcı ilişkisi ise çoklu doğrusal regresyon analizi ile test edilmiştir. Analizler için SPSS-22 istatistik programı kullanılmıştır. Araştırma verilerinin normallik varsayımını karşılayıp karşılanmadığını belirlemek için basıklık ve çarpıklık değerlerine bakılmıştır. Sonuçlar Tablo'2 de gösterilmiştir.

Tablo 2: Araştırma Değişkenlerine İlişkin Çarpıklık ve Basıklık Değerleri

\begin{tabular}{|c|c|c|c|c|c|c|c|}
\hline \multirow[b]{2}{*}{ Değişkenler } & \multirow[b]{2}{*}{$\mathbf{N}$} & \multirow{2}{*}{$\begin{array}{c}\text { Aritmetik } \\
\text { Ortalama } \\
\text { İstatistik }\end{array}$} & \multirow{2}{*}{$\begin{array}{c}\text { Standart } \\
\text { Sapma } \\
\text { İstatistik } \\
\end{array}$} & \multicolumn{2}{|c|}{ Çarpıklık } & \multicolumn{2}{|c|}{ Basıklık } \\
\hline & & & & İstatistik & S.H. & İstatistik & S.H \\
\hline Psikolojik Sermaye & 221 & 95,12 & 12,38 & -.46 & .16 & .64 & .33 \\
\hline İş Doyumu & 221 & 75,27 & 11,58 & -.63 & .16 & .85 & .33 \\
\hline Minnettarlık & 221 & 27,49 & 5,74 & $-1,11$ & .16 & 1,61 & .33 \\
\hline
\end{tabular}

Tablo 2'de verilerin normallik varsayımını karşılayıp karşılamadığını belirlemek için basıklık ve çarpıklık değerlerine bakılmıştır. Psikolojik sermaye düzeylerine ilişkin basıklık ve çarpıklık değerlerinin -.46 ile .64; iş doyumlarına ilişkin basıklık ve çarpıklık değerlerinin -.63 ile .85 ; minnettarlık düzeylerine ilişkin basıklık ve çarpıklık değerlerinin -1.11 ile 1.61 arasında olduğu belirlenmiştir. Ayrıca P-P grafiğinin çizilmesi sonucunda değişkenlere ait verilerin doğrusallık varsayımını da karşıladığı gözlenmiştir.

\section{Bulgular}

Öğretmenlerin Minnettarlık Puanları ile İş Doyumu ve Psikolojik Sermaye Düzeyleri Arasındaki İlişkiler

Öğretmenlerin minnettarlık puanları ile psikolojik sermaye ve iş doyumları arasındaki ilişki düzeyini belirlemek amacıyla Pearson Korelasyon analizi yapılmıştır. Elde edilen bulgular Tablo 3'de gösterilmiştir. 
Tablo 3: Minnettarlık, Psikolojik Sermaye, İş Doyumu Arasındaki Pearson Korelasyon Analizi Sonuçları

\begin{tabular}{cccc}
\hline Değişken & Minnettarlık & İş Doyumu & Psikolojik Sermaye \\
\hline Minnettarlık & 1 & & \\
\hline İş Doyumu & $.34^{* *}$ & 1 & \\
\hline Psikolojik Sermaye & $.24^{* *}$ & $.35^{* *}$ & 1 \\
\hline
\end{tabular}

${ }^{*} \mathbf{p}<.05, * * \mathbf{p}<.01$

Tablo 3 incelendiğinde, öğretmenlerin minnettarlık puanları ile iş doyumu ve psikolojik sermaye puanları arasında anlamlı bir ilişki olup olmadığını belirlemek amacıyla yapılan çoklu korelasyon analizi sonucunda, öğretmenlerin minnettarlık ile psikolojik sermaye düzeyleri arasında anlamlı ve pozitif yönde bir ilişki $\left(\mathrm{r}_{221}=.24, \mathrm{p}<.01\right)$ ve minnettarlı ile iş doyumu arasında anlamlı ve pozitif yönde bir ilişki $\left(\mathrm{r}_{221}=.34, \mathrm{p}<.01\right)$ olduğu belirlenmiştir. Bu bulgular sonucunda, öğretmenlerin minnettarlık puanlarının artması durumunda iş doyumu ve psikolojik sermaye puanlarının artacağ 1 söylenebilir.

\section{Öğretmenlerin Minnettarlık Düzeylerinin Yordanmasına İlişskin Bulgular}

Araştırmada öğretmenlerin psikolojik sermaye ve iş doyumlarının minnettarlığı yordayıp yordamadığına ilişkin çoklu doğrusal regresyon analizi uygulanmıştır. Çoklu doğrusal regresyon analizi bulguları aşağıda sunulmuştur.

Tablo 4: İş Doyumu ve Psikolojik Sermayenin Minnettarlığı Yordamasına İlişkin Aşamalı Çoklu

\begin{tabular}{lccccc}
\multicolumn{5}{c}{ Regresyon Analizi Sonuçlar1 } \\
\hline Değissken & B & Standart Hata & $\boldsymbol{\beta}$ & $\mathbf{t}$ & $\mathbf{p}$ \\
\hline 1. Sabit & 14.75 & 2.40 & & 6.15 & .00 \\
İş doyumu & .17 & .03 & .34 & 5.37 & .00 \\
2. Sabit & 10.36 & 3.17 & & 3.27 & .00 \\
İş Doyumu & .15 & .03 & .29 & 4.34 & .00 \\
Psikolojik Sermaye & .07 & .03 & .14 & 2.10 & .03 \\
\hline
\end{tabular}

$* * \mathbf{p}<.01$

Bağımlı Değişken: Minnettarlık

1. Aşama: $\mathrm{R}=.34, \mathrm{R}^{2}=.11, \mathrm{~F}(1-219)=28.88, \mathrm{p}<.01$

2. Aşama: $\mathrm{R}=.37, \mathrm{R}^{2}=.13, \mathrm{~F}(2-218)=16.88, \mathrm{p}<.01$

Tablo 4 incelendiğinde, öğretmenlerin psikolojik sermaye puanları ile iş doyumu puanlarının minnettarlığı yordamasına yönelik aşamalı çoklu regresyon analiz sonuçları istatistiksel olarak

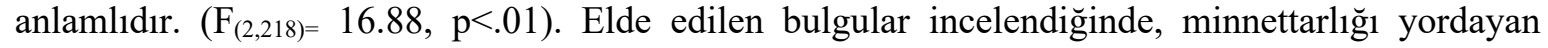
değişkenlere ilişkin aşamalı çoklu regresyon analizi sonuçlarına göre, 1. aşamada iş doyumu minnettarlığın \%11'ni açıklarken, 2. aşamada iş doyumunun psikolojik sermaye ile birlikte minnettarlığın \%13'ünü açıkladığı gözlemlenmiştir. Bu sonuç, öğretmenlerin minnettarlık düzeylerindeki $\% 13$ oranındaki varyansın iş doyumu ve psikolojik sermayeleri tarafından açıklandığını, tablodaki standardize edilmiş beta katsayısı ve t değerleri incelendiğinde, minnettarlık düzeylerini açıklamada her iki bağımsız değişkenin (iş doyumu ve psikolojik sermaye) anlamlı katkısının olduğu $(\beta=.14, \mathrm{p}<.01, \beta=.29, \mathrm{p}<.01)$, iş doyumu değişkeninin minnettarlığı psikolojik 
sermayeyeye göre daha fazla açıkladığ 1 söylenebilir. Tüm bu bulgular sonucunda, öğretmenlerin psikolojik sermaye ve iş doyum puanlarının minnettarlık düzeylerinin anlamlı bir yordayıcısı olduğunu söyleyebiliriz.

Öğretmenlerin minnettarlık puanlarının cinsiyetlerine göre anlamlı olarak farklılaşıp farklılaşmadığını belirlemek amacıyla yapılan analiz sonuçlarına yönelik bulgular tablo 5'de gösterilmiştir.

\section{Öğretmenlerin Minnettarlık Puanlarının Cinsiyete Göre Farklılaşma Durumuna İlişkin Bulgular}

Tablo 5: Öğretmenlerin Minnettarlık Düzeylerinin Cinsiyete Göre İncelenmesi

\begin{tabular}{ccccccc}
\hline Değişken & Cinsiyet & $\mathbf{N}$ & $\overline{\mathbf{X}}$ & S.s & t & p \\
\hline \multirow{2}{*}{ Minnettarlık } & Erkek & 84 & 26.45 & 6.58 & & \\
\cline { 2 - 6 } & Kadın & 137 & 28.13 & 5.08 & -2.13 & \multirow{2}{*}{.03} \\
\hline
\end{tabular}

Tablo 5 incelendiğinde, öğretmenlerde minnettarlık düzeylerinin cinsiyete göre anlamlı farklılaşıp farklılaşmadığını belirlemek amacıyla yapılan bağımsız örneklemler t testi sonucunda minnettarlık düzeyleri açısından cinsiyete göre anlamlı farklılaşma olduğu gözlemlenmiştir $\left(\mathrm{t}_{219}=\right.$ $2.13, \mathrm{p}<.05)$. Farkın kaynağını belirlemek için aritmetik ortalamalar incelendiğinde minnettarlık düzeylerinde erkeklerin aritmetik ortalamasının $(\overline{\mathrm{X}}=26.45)$ olduğu, buna karşın kadınların aritmetik ortalamasının ( $\overline{\mathrm{X}}=28.13)$ olduğu gözlemlenmiştir. Bu sonuçlar, kadın öğretmenlerin erkek öğretmenlere göre anlamlı düzeyde daha fazla minnettarlık taşıdığını göstermektedir.

\section{Tartışma, Sonuç ve Öneriler}

$\mathrm{Bu}$ araştırmada öğretmenlerin psikolojik sermaye ve iş doyumu puanlarının minnettarlığ yordama düzeylerine etkisi ve cinsiyete göre minnettarlık düzeylerinde anlamlı farkın olup olmadığı incelenmiştir. Araştırma sonucu elde edilen bulgular incelendiğinde öğretmenlerin psikolojik sermaye ve iş doyumu puanlarındaki artışı minnettarlık düzeylerinde yordayıcı bir etkiye sahip olduğu sonucuna ulaşılmıştır. Yine, iş doyumu ile psikolojik sermayenin minnettarlığı düşük seviyede, anlamlı olarak yordadığı belirlenmiştir. Ayrıca cinsiyete göre minnettarlık düzeylerinde anlamlı bir farklılık gösterdiği, kadınların erkeklere göre minnettarlık düzeyleri ortalama puanının daha fazla olduğu belirlenmiştir.

Öğretmenlerin minnettarlık düzeylerini ele alan çalışmalar incelendiğinde Howells ve Cumming, (2011), öğretmenlerin eğitim kurumlarında karşılaştıkları problemlerle baş etme noktasında minnettarlık düzeylerini geliştirmenin önemli bir etkiye sahip olduğunu belirtmiştir. Yine yapılan çalışmalarda, öğretmenlerin minnettarlıklarının artması durumunda okul memnuniyeti, okula bağl1lık düzeylerininde artacağı belirtilmiştir (Chan, 2010; Chin-Ting ve Yin Yeh, 2014). Öğretmenlerin çalıştıkları yerde mutluluklarına psikolojik sermaye düzeyleri ile minnettarlık düzeyleri ve iyi oluşlarının olumlu yordayıcı etkisinin olduğu belirlenmiştir (Kun ve Gadanecz, 2019). Song ve arkadaşları (2019) yaptıkları araştırmada, öğretmenlerin depresyondan kurtulmaları üzerinde pozitif psikolojinin önemli kavramları olan, mutlu olma, iyi hissetme ve minnettarlığın pozitif yönde etkilerinin olduğunu belirtmişlerdir. Farklı bir çalışmada, Waters (2012), öğretmenlerin iş doyum düzeylerini tahmin etmede minnettarlık düzeylerinin pozitif etkisinin olduğunu belirtmiştir. Azi (2016), yaptığı araştırmada öğretmenlerin iş doyumlarının artırılması durumunda ikincil kazançlar arasında minnettarlık duygularınında artabileceğini belirtmiştir. Yurtdışında yapılan araştırmalar incelendiğinde psikolojik sermaye ve iş doyumunun, minnettarlıkla olan ilişkisine yönelik birlikte yapılan çalışma bulgularına rastlanmamıştır. Genel olarak değişkenler ayrı ayrı ele alınmış ve minnettarlıkla ile birlikte pozitif psikolojiye özgü benzer kavramlarla çalışmalar yapıldığı gözlemlenmiştir. Türkiye' de yapılan çalışmalar incelendiğinde Demirbağ (2016a) ilkokul 
öğretmenlerine uygulanan eğitim programının minnettarlık düzeylerine olan etkisini incelemiş ve uygulanan eğitim programının öğretmenlerin minnettarlık düzeylerinde pozitif yönde artışa sebep olduğunu belirtmiştir. Yine Özsoylar (2019) yaptığı araştırmada öğretmenleri de kapsayan yetişkinlere yönelik çalışmada, minnettarlık yazma çalışmasının psikolojik sermaye düzeyleri üzerinde pozitif yönde bir etkiye sahip olduğunu belirtmiştir.

Araştırmanın bir diğer bulgusu öğretmenlerin cinsiyetlerine göre minnettarlık düzeylerinde anlamlı bir farklılaşma olduğuna yöneliktir. Araştırma bulgu sonuçları incelendiğinde kadınların minnettarlık düzeylerinin erkeklere göre daha yüksek olduğu gözlemlenmiştir. $\mathrm{Bu}$ farkın oluşmasında kadınların doğuştan sahip oldukları kişilik özelliklerinin erkeklere oranla daha duygusal, kabullenme ve iyimserlik düzeylerinin daha yüksek olması ve anaç ruhlu bir yapıya sahip olmaları gösterilebilir. Alanyazında yapılan çalışmalar incelendiğinde araştırma bulgularına benzer çalışmalara rastlamak mümkündür (Howells, 2014; Yoosefvand ve Rasekh, 2014). Araştırma bulgusundan farklı olarak yapılan çalışmada, Khan ve Singh (2013) cinsiyetler arası minnettarlık düzeylerindeki farklılıkların ele alındığı araştırmada, erkek öğretmenlerin minnettarlık ortalamalarının, bayan öğretmenlere göre daha yüksek olduğunu belirtmişlerdir. Türkiye'de (Araz ve Erdugan, 2017a) tarafından minnettarlık dışavurum ölçeği geliştirme çalışmasında, katılımcıların cinsiyetlerine göre minnettarlık dışavurumlarında anlamlı bir farklılık olmadığ gözlemlenmiştir.

Öğretmenlik mesleğini yerine getiren bireylerin genel iyi oluşlarını, akademik olarak verimli olmalarını, bağımsız çalışabilmelerini, geleceğe pozitif bakabilmelerine ve iş tatminlerini kapsayan bu iki değişken minnettarlık eğilimlerini olumlu yönde etkileyebilmektedir. Eğitim kurumlarında çalışan bireylerin minnettarlık düzeylerinin artırılması olumlu bir okul kültürü oluşturması yanı sıra öğrenci ve velilerde olumlu kazanımlar oluşturabilmesi bakımından oldukça önemli olduğu düşünülmektedir. Ayrıca eğitim kurumlarında, minnettarlık eğilimini artırmaya yönelik çalışmaların son yıllarda ivme kazandığg gözlemlendiğinde yapılacak çalışmaların eğitimin doğal bir parçası ve eğitim pedagojisinin güçlü bir yönü olacağı söylenebilir.

$\mathrm{Bu}$ araştırma Erzurum ili merkezinde görevli 221 öğretmen ile sınırlıdır. Çalışma sonucunda yapılacak öneriler şu şekilde sıralanabilir:

1-) Öğretmenlerin minnettarlık düzeylerine yordayıcı etki sağladağı belirlenen psikolojik sermaye ve iş doyumlarını artırabilecek sosyo ekonomik faktörlerin belirlenerek bu faktörlere yönelik iyileştirici, düzeltici çalışmalar yapılması önerilebilir.

2-) Öğretmenlerde minnettarlık düzeylerini artımaya yönelik, iş doyumu, psikolojik sermaye ve benzer birkaç değişkeninde dahil edilmesiyle uzman kişiler tarafından bir minnettarlık geliştirme programının hazırlanarak öğretmenlere uygulanması önerilebilir.

3-) Cinsiyete göre kadınların erkeklere göre minnettarlık düzeyi puan ortalamalarının yüksek olduğu belirlenmiştir. Sonraki araştırmalarda çalışma grubundaki katılımcı sayısı artırılarak ve cinsiyete göre katılımcıların yakın sayılarda olmasına dikkat edilerek, farklı türde yeni araştırmalar yapılması önerilebilir.

\section{Kaynakça}

Akçay, H.V. (2014). Psikolojik sermaye ölçeği uyarlaması: geçerlik ve güvenirlik çalışması. Üçüncü Sektör Sosyal Ekonomi Dergisi, 49(2), 72-85, https://doi.org/10.15659/3.sektor-sosyalekonomi.19.03.1091

Akın, U. ve Koçak, R. (2007). Öğretmenlerin sınıf yönetimi becerileri ile iş doyumları arasındaki ilişki. Kuram ve Uygulamada Ĕgitim Yönetimi Dergisi,51(51), 353-370, https://doi.org/10.14527/kuey.2014.009 
Öğretmenlerin Minnettarlık, Psikolojik Sermaye ve İş Doyum Düzeyleri Arasındaki...

Akman, Y. (2016). Öğretmenlerin psikolojik sermaye algılarının çeşitli değişkenlere göre incelenmesi. Dicle Üniversitesi Ziya Gökalp Eğitim Fakültesi Dergisi, 28, 268-277, https://doi.org/10.14582/duzgef.729

Araz, A. ve Erdugan, C. (2017). Minnettarlık dışa vurum ölçeği geliştirme çalışması. Nesne Dergisi, $5(11), 404-425$.

Aydın, A., Yılmaz, K. ve Altınkurt, Y. (2013). Eğitim yönetiminde pozitif psikoloji. Uluslararası Insan Bilimleri Dergisi, 10(1), 1470-1490.

Azi, S.D. (2016). Enhancing job satisfaction for teachers: a strategy for achieving transformation of secondary education in Nigeria. Journal of Education and Practice, 7(13). 37-41.

Baycan, F.A. (1985). Farklı gruplarda çalışan gruplarda iş doyumunun bazı yönlerinin analizi. Yayınlanmamış Yüksek Lisans Tezi, Boğaziçi Üniversitesi Sosyal Bilimler Enstitüsü, İstanbul.

Biçkes, D. M., Yılmaz, C., Demirtaş, Ö., ve Ayşegül, U. (2014). Duygusal emek ile iş tatmini arasındaki ilişkide psikolojik sermayenin aracılık rolü: Bir alan çalışması. Eskişehir Osmangazi Üniversitesi İktisadi ve İdari Bilimler Dergisi, 9(2), 97-122, https://doi.org/10.17153/oguiibf.523723

Boamah, S. ve Laschinger, H. (2011). Engaging new nurses: the role of psychological capital and workplace empowerment. Journal of Research in Nursing, 20 (4). 265-277, https://doi.org/10.1177/1744987114527302

Bozgeyikli, H., Avcı, A. ve Navruz, B. (2017). Öğretmenlerin psikolojik sermaye düzeyleri ile örgütsel vatandaşlık davranışları arasındaki ilişkinin yapısal eşitlik modeli ile incelenmesi. Electronic $\quad$ Turkish $\quad$ Studies, 12(6). https://doi.org/10.7827/turkishstudies.11574

Büyüköztürk, Ş. (2015). Sosyal bilimler için veri analizi el kitabı. Ankara: Pegem Akademi Yayınları.

Canbay, S. (2007). İlköğretim okullarında çalışan öğretmenlerin iş doyumu ve denetim odağı ilişkisi. Yayımlanmamış Yüksek Lisans Tezi, Dokuz Eylül Üniversitesi, Eğitim Bilimleri Enstitüsü, İzmir.

Chan, D.W. (2010). Gratitude, gratitude intervention and subjective well-being among Chinese school teachers in Hong Kong. Educational Psychology, 30(2), 139-153, https://doi.org/10.1080/01443410903493934

Chin Ting, S. ve Yin Yeh, L. (2014). Teacher loyalty of elementary schools in Taiwan: The contribution of gratitude and relationship quality. School Leadership \& Management, 34(1), 85-101, https://doi.org/10.1080/13632434.2013.813453

Çakmak-Sünkür, M. ve Arabacı, İ.B. (2017). Öğretmenlerin pozitif psikolojik sermaye algılarının iş doyumları ve örgütsel bağl1lıkları üzerindeki etkisi. Electronic Journal of Social Sciences, 16(62). 890-909, https://doi.org/10.17755/esosder.282130

Çifçi, T. ve Dikmenli, Y. (2015). Coğrafya öğretmenlerinin iş doyumu ve iş yaşamında yalnızlık düzeylerinin incelenmesi. Akademik Sosyal Araştırmalar Dergisi, 3(21), 142-160, https://doi.org/10.16992/asos.946

Demirbağ, T. (2016). Teşekkür ederim minnettarlık eğitimi programının (temep) ilkokul ögretmenlerinin minnettarlık düzeyleri üzerindeki etkisi. Yayımlanmamış yüksek lisans tezi. Uludağ Üniversitesi Eğitim Bilimleri Enstitüsü, Bursa. 
Dilsiz, B. (2006). Konya ilindeki ortaöğretim okullarında çalışan öğretmenlerin tükenmişlik ve iş doyumu düzeylerinin bölgelere göre değerlendirilmesinin çok değişkenli istatistiksel analizi. Yayınlanmamış Yüksek Lisans Tezi, Selçuk Üniversitesi Fen Bilimleri Enstitüsü, Konya.

Emmons, R.A. ve Stern, R. (2013). Gratitude as a psychotherapeutic intervention. Journal of Clinical Psychology, 69(8), 846-855, https://doi.org/10.1002/jclp.22020

Ertürk, E. ve Keçecioğlu, T. (2012). Çalışanların iş doyumları ile mesleki tükenmişlik düzeyleri arasındaki ilişkiler: Öğretmenler üzerine örnek bir uygulama. Ege Akademik Bakış Dergisi, 12(1), 39-52, https://doi.org/10.21121/eab.2012119545

Filiz, Z. (2014). An analysis of the levels of job satisfaction and life satisfaction of the academic staff. Social Indicator Research. 116, 793-808, https://doi.org/10.1007/s11205-013-0319-6

Goldsmith, A.H., Darity, W. ve Veum, J.R. (1998). Race, cognitive skills, psychological capital and wages, Review of Black Political Economy, 26(2), 13-22, https://doi.org/10.1007/s12114998-1001-0

Göcen, G. (2015). 11-12 Yaş grubundaki çocukların minnettarlıkları ve hayat memnuniyetlerine etki eden aile ile ilgili faktörler. Değerler Eğitimi Dergisi, 29(13), 83-116, https://doi.org/10.2399/tahd.13.63835

Howells, K. (2014). An exploration of the role of gratitude in enhancing teacher-student relationships. Teaching and Education, 42, 58-67, https://doi.org/10.1016/j.tate.2014.04.004

Howells, K. ve Cumming, J. (2011). Exploring the role of gratitude in the professional experience of pre-service teachers. Teaching Education, 23(1), 71-88, https://doi.org/10.1080/10476210.2011.638370

Işık-Terzi, Ş. ve Ergüner-Tekinalp, B. (2017). The effects of gratitude journaling on turkish first year college students college adjustment, life satisfaction and positive affect. International Journal for the Advancement of Counselling, 39(2), 164-175, https://doi.org/10.1007/s10447-017-9289-8

İlbay, A.B. ve Sarıçam, H. (2015). The predictor role of gratitude and psychological vulnerability on forgiveness. International Journal of Research Studies in Psychology, 4(4), 61-74, https://doi.org/10.5861/ijrsp.2015.1305

Kara, M. (2010). The relation of job satisfaction with happiness and success level. Yayınlanmamış Yüksek Lisans Tezi. Marmara Üniversitesi Sosyal Bilimler Enstitüsü, İstanbul.

Kaya, A., Balay, R., ve Demirci, Z. (2014). Ortaöğretimde Görev Yapan Öğretmenlerin Psikolojik Sermaye Düzeylerinin İncelenmesi (Şanllurfa ili Örneği). Electronic Journal of Social Sciences, 13(48). 47-68, https://doi.org/10.5861/ijrsp.2015.1305

Kelekçi, H. ve Yılmaz, K . (2015). Öğretmenlerin pozitif psikolojik sermayeleri ile yeterlik inançları arasındaki ilişki. Mersin Üniversitesi Eğitim Fakültesi Dergisi, 11 (3), 992-1007, https://doi.org/10.17860/efd.96988

Khan, I. ve Singh, N. (2013). A study on gender differences on gratitude, spirituality and forgiveness among school teachers. International Journal of Applied Sciences \& Engineering, 1(1), 914.

Killen, A. ve Macaskill, A.(2015). Using a gratitude intervention to enhance well-being 123 in older adults. Journal Happiness Studies, 16, 947-964, https://doi.org/10.1007/s10902-014-9542-3 
Öğretmenlerin Minnettarlık, Psikolojik Sermaye ve İş Doyum Düzeyleri Arasındaki...

Kun, A. ve Gadanecz, P. (2019). Workplace happiness, well-being and their relationship with psychological capital: A study of Hungarian Teachers. Current Psychology, 2-15, https://doi.org/10.1007/s12144-019-00550-0

Luthans F. ve Avolio B.J. (2003). Authentic leadership: A positive developmental approach. In Cameron KS, Dutton JE, Quinn RE (Eds.), Positive Organizational Scholarship, 241-261.

Luthans, F., Avolio, B.J., Avey, J.B. ve Norman, S.M. (2007). Positive psychological capital: Measurement and relationship with performance and satisfaction. Personnel psychology, 60(3), 541-572, https://doi.org/10.1111/j.1744-6570.2007.00083.x

McCullough, M. E., Kilpatrick, S. D., Emmons, R. A.ve Larson, D. B. (2001). Is gratitude a moral affect?. Psychological Bulletin, 127, 249-266, https://doi.org/10.1037/0033-2909.127.2.249

McCullough, M. E., Emmons, R.A. ve Tsang, J.A. (2002). The grateful disposition: conceptual and empirical topography. Journal of Personality and Social Psychology, 82(1), 112-127.

Oğuz-Duran, N. ve Tan, Ş. (2013). Minnettarlık ve yaşam amaçları yazma çalışmalarının öznel iyi oluşa etkisi. Türk Psikolojik Danışma ve Rehberlik Dergisi, 4(40), 154-166.

Özdemir, M. ve Gören S.Ç. (2016). Politik beceri ve psikolojik sermaye arasındaki ilişkinin öğretmen görüşlerine göre incelenmesi. Hacettepe Üniversitesi Eğitim Fakültesi Dergisi, 31(2), 333-345, https://doi.org/10.16986/huje.2016015699

Özoylar, Ö. (2019). Çalı̧̧anların minnettarlık algısı ile psikolojik sermaye algısı arasındaki ilişki üzerine görgül bir araştırma. Yayınlanmamış Yüksek Lisans Tezi. Marmara Üniversitesi Sosyal Bilimler Enstütisi, İstanbul.

Peterson, S. J., Luthans, F., Avolio, B. J., Walumbwa, F. O. ve Zhang, Z. (2011). Psychological capital and employee performance: A latent growth modeling approach. Personnel Psychology, 64(2), 427-450, https://doi.org/10.1111/j.1744-6570.2011.01215.x

Song, R., Sun, N. ve Song, X. (2019). The efficacy of psychological capital intervention (pc1) for depression from the perspective of positive psychology: A pilot study. Frontiers in Psycohology, 10, 1-21, https://doi.org/10.3389/fpsyg.2019.01816

Şahin, İ. (2013). Öğretmenlerin iş doyumu düzeyleri. Yüzüncü Yıl Üniversitesi Eğitim Fakültesi Dergisi, 10(1), 142-167.

Telef, B. (2011). Öğretmenlerin öz-yeterlikleri, iş doyumları, yaşam doyumları ve tükenmişliklerinin incelenmesi, Illkögretim Online Dergisi, 10(1), 91-108.

Terzi, S. (2017). Öğretmenlerin iş doyumları ile mutlulukları arasındaki ilişkinin incelenmesi. 21. Yüzyılda Eğitim ve Toplum Eğitim Bilimleri ve Sosyal Araştırmalar Dergisi, 6(17), 475-487, https://doi.org/10.15869/itobiad.445560

Tösten, R. ve Özgan, H. (2017). Öğretmenlerin pozitif psikolojik sermayelerine ilişkin algılarının incelenmesi. Elektronik Sosyal Bilimler Dergisi, 16(62), 867-889, https://doi.org/10.17755/esosder.306900

Waters, L. (2012). Predicting job satisfaction: contributions of individual gratitude and institutionalized gratitude. Scientific Research, 3(12), 1174-1176, https://doi.org/10.4236/psych.2012.312a173

Wood, A.M., Froh, J. ve. Geraghty, A.W.A. (2010). Gratitude and well-being: A review and theoretical integration. Clinical Psychology Review, 30(7), 890- 905, https://doi.org/10.1016/j.cpr.2010.03.005 
Yakut, S. ve Certel, H. (2016). Öğretmenlerde yalnızlık düzeyinin çeşitli değişkenler açısından incelenmesi. Birey ve Toplum Sosyal Bilimler Dergisi, 6(1), 69-94, https://doi.org/10.29029/busbed.494469

Yalçın, D. (2019). Öğretmenlerin pozitif psikolojik sermaye düzeylerinin incelenmesi. Anadolu Üniversitesi Sosyal Bilimler Dergisi, 19 (1), 13-26, https://doi.org/10.18037/ausbd.550238

Yoosefvand, A. ve Rasekh, A.E. (2014). Gender Differences in the Expression of Gratitude by Persian Speakers. Journal of Applied Linguistics and Language Research, 1(1), 100-117.

Yüksel, A. ve Oğuz Duran, N. (2012). Minnettarlık Ölçeği'nin yetişkinlere uyarlanması: Geçerlik ve güvenirlik çalışmaları. Çağdaş Ĕ̆itim Dergisi Akademik, 1(1), 31-40, https://doi.org/10.1501/ozlegt_0000000139 